\title{
Medicinal properties of amniotic stem cells
}

\section{Propriedades medicinais de células-tronco amnióticas}

\author{
Braulio Fernandes de Carvalho ${ }^{1}$, Deny Berg de Carvalho Sousa ${ }^{2}$, Aloísio José Portela Neto ${ }^{3}$, João Paulo Silva \\ Nunes ${ }^{4}$, Paula Andrea Sampaio de Vasconcelos ${ }^{5}$ \\ ${ }^{1}$ Department of Biological Sciences, University of Tsukuba, Japan \\ 2 Department of Endodontics, Federal University of Piauí - UFPI, Brazil \\ ${ }^{3}$ Department of Nursery, Unified Teaching Center of Teresina - CEUT, Brazil \\ ${ }^{4}$ Department of General Biology, Federal University of Minas Gerais - UFMG, Brazil \\ ${ }^{5}$ Department of Genetics, State University of São Paulo - UNESP, Brazil
}

\section{ABSTRACT}

The current regenerative medicine is still incapable of creating full organs in vitro. Transplantation queues are a worrying problem in most of countries, without an apparent coming solution. The research with several types of stem cells has shown that the use of cells to repair damaged organ can be as effective as replacing the whole organ. Particularly, stem cells populations from the amniotic sac possess properties beyond the physical constitution and are capable of secreting cytokines with anti-inflammatory action and growth factors with potential to mobilize stem cells from the own body. Transplantation of amniotic stem cells can be an alternative to optimize surgical procedures, to increase organ and stem cells transplantation success rate, to help in the treatment of several diseases and to accelerate patient's recovery.

Keywords: Adult stem cells, Amnion, Cytokine, Inflammation, Organ transplantation.

\section{RESUMO}

O avanço da medicina regenerativa ainda se mostra incapaz de construir órgãos completos in vitro. As filas de transplantes são longas e preocupantes, sem uma solução aparente por vir. A pesquisa com vários tipos de células-tronco tem demonstrado que usar células para reparar órgãos pode ser tão eficiente quanto substituí-los. Particularmente, células-tronco adultas do saco amniótico têm demonstrado propriedades além da sua constituição física, como a capacidade de secretar citocinas antiinflamatórias e fatores de crescimento capazes de mobilizar células-tronco adultas do próprio corpo. O transplante de células tronco amnióticas pode ser uma alternativa para melhorar procedimentos cirúrgicos, aumentar o sucesso em transplantes de órgãos e de outros tipos de células-tronco, ajudar no tratamento de várias doenças e acelerar a recuperação de pacientes. Palavras-chave: Células-tronco adultas, Âmnio, Citocina, Inflamação, Transplante de órgãos.

\section{OPINION PAPER}

A lot was promised with the isolation of embryonic stem cells, the development of cloning and the human genome project. It was expected that scientists would be able to create in vitro whole new organs and transplant them into patients. More than a decade of research showed us organ development and gene regulation is more complex than initially imagined (Asashima et al., 2008). Scientists still unable to growth full human organs and transplantation queue in hospital still long and worrying.

Our failure, however, might be due to a wrong approach in way we see diseases. What if, instead of replacing an organ, doctors and scientist could repair the damaged tissue? What if we could act quickly and avoid permanent damage to organs?
Discoveries in stem cells research field have increased enormously and immense budgets were spent and are yet to be invested (Carvalho et al., 2013a). Scientists were able to find several sources of stem cells, from embryo and fetal tissues to populations of stem cells in adult individuals (Costa, 2001; Klimanskaya et al., 2006; Vasconcelos et al., 2009). Even more stunning, they could also create stem cells derived from somatic cells by environmental and genetic reprogramming (Nakanishi et al., 2008).

The formation in vitro of an organ demonstrated to be of extreme complexity (Kurisaki et al., 2010). Building an organ involves more than differentiating stem cells to a cell type, it also involves several layers of different cells in different organization, permeate of neural and vascular networks in a tridimensional arrange.

A simpler and counteracting approach is to insert in the tissue differentiated stem cells similar to the target organ. This method showed promising results, but also full of difficulties, some of them expected. For example, inserting neuronal cells into a damaged neural tissue might not be efficient $\mathrm{Hu}$ et al., 2013). First, cells have to be properly engrafted. For that, it needs access to blood vessels. Second, the graft has to integrate itself with surrounding neuronal cells to be able to interact. If the neural cells can't communicate with the rest of neural network, they aren't functional.

Other delicate issue is: is there any effective benefit to insert thousands of cells into organs with millions or billions of cells? The answer varies and will depend where, what type of stem cells is inserted and its degree of differentiation. Some studies with amniotic stem cells show, surprisingly, most of cells don't get engrafted, but organs show health improvement (Bailo et al., 2004). How can patients be benefited from transplanted cells with limited lifespan? Transplantation of some types of stem cells can be beneficial even when cells don't engraft. It is due to cytokines and growth factors stem cells release (Zhao et al., 2004). These cytokines act as immune modulators, reducing lymphocytes, netrophils and macrocytes response, decreasing their activation and chemotaxis (Miki et al., 2005; Carvalho et al., 2013b). Inflammation and fibrosis were beneficial to human being in the past, when stopping a bleeding and closing a wound had to be done quickly to avoid infection and blood loss. But inflammation and fibrosis also don't give the proper time to the body to heal properly and lead to loss of function by substitution of organ cells mainly with fibroblasts, creating scars.

Studies with amniotic epithelial and mesenchymal stem cells showed that, when inserted intravenously in mice bodies with systemic diseases, these cells were able to find the injured organs and engraft into most of them, bringing an increase on health status of subjects. When amniotic stem cells were inserted by parenteral way, however, cells couldn't migrate to injured sites, but the transplantation was still beneficial, showing that immune modulators were
Recebido em 23-08-2013

Aceito em 01-09-2013
Copyright - Todos os direitos reservados a

SBRA - Sociedade Brasileira de Reprodução Assistida 
being secreted by cells and act systemically. Even extract obtained from supernatant of amniotic stem cell cultures showed action upon immune cells in vitro (Kamiya et al., 2005). Figure 1 simplifies the possible applications for amniotic stem cells.

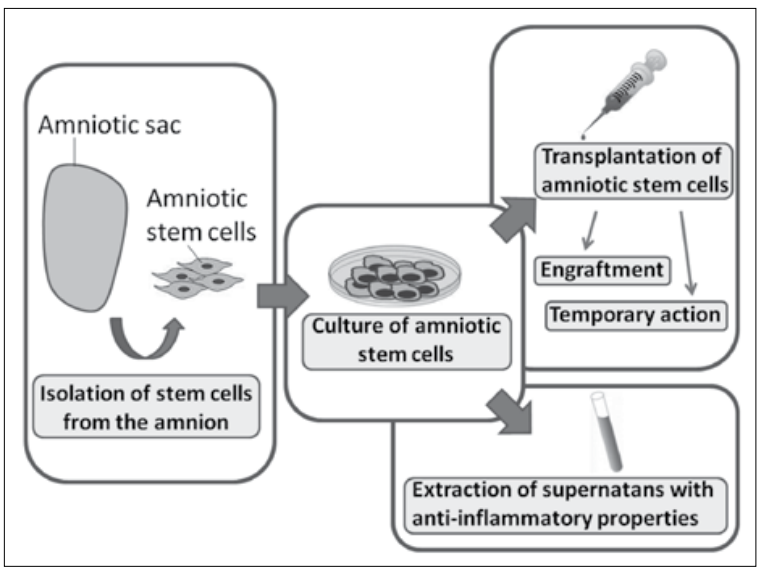

Figure 1. The amniotic stem cell research

Amniotic cells probably have these properties because the amnion is a fetal tissue that has to interact with maternal tissues and regulate maternal immunological response to a strange body (the fetus) and avoid rejection. Amniotic cells properties could be summarized as: 1 ) low immunogenicity; 2) embryonic molecular markers; 3 ) epithelial and mesenchymal population of stem cells; 4) capacity to differentiate into the three germ layers; 5) immune-modulatory potential; 6) don't lead to teratoma formation; 7) virtually no ethical issue, since they are obtained from discarded placenta (Miki et al., 2005). There is no such thing as ideal stem cells, but amniotic populations of stem cells congregate so many advantageous properties that these cells should be investigated intensively.

Obtaining and transplanting cells is easier and less ethically controversial than obtaining and transplanting full organs. Populations of adult stem cells can be found in discarded tissues, as fat and placenta. Making a procedure simpler also amplifies its reach to the public health system and to a greater portion of people. And, if transplantation of full organ is still necessary, why don't we do it together with cells with anti-inflammatory properties or vascular progenitors, to accelerate blood vessel formation and engraftment? In conclusion, the transplantation of stem cells, specially differentiated amniotic stem cells, can be an aid to disease treatment and into surgical procedures, including transplantation of organs or other stem cells since amniotic cells are capable to find injured tissue, secrete anti-inflammatory substances and mobilize adult stem cells from the own patient. This method accelerates recovery and increases surgical and organ transplantation success rate.

Patients in transplantation queues can't wait until science master the creation of the human body. While we can't grow full organs, transplanting cells and optimizing the medicinal substances they provide seems a more logical, ethical and efficient approach.

\section{Corresponding Author}

Braulio Fernandes de Carvalho

Tel.: +81 (080)3170-8546 (Japan)

E-mail: hazbio@gmail.com

CARVALHO, Braulio Fernandes de

Stem Cell Differentiation Research Team,

Research Center for Stem Cell Engineering,

National Institute for Advanced Industrial Science and Technology AIST

Tsukuba Central 4-1-3106 Higashi 1-1-1, Tsukuba, Ibaraki, Japan 305-8562

\section{REFERENCES}

Asashima M, Michiue T, Kurisaki A. Elucidation of the role of activin in organogenesis using a multiple organ induction system with amphibian and mouse undifferentiated cells in vitro. Dev Growth Differ. 2008; 50:(Suppl 1)S35-45.

Bailo $M$, Soncini $M$, Vertua $E$, Signoroni PB, Sanzone S, Lombardi G, Arienti D, Calamani F, Zatti D, Paul P, Albertini A, Zorzi F, et al. Engraftment potential of human amnion and chorion cells derived from term placenta. Transplantation 2004; 78:1439-1448.

Carvalho, BF; Sene, IS, Carvalho, ALF, Vasconcelos, PAS. The current need to continue researching with embryonic stem cell. JBRA Assist Reprod. 2013; 17(1):53-55.

Carvalho, BF; Sene, IS; Padua, LEM; Da Silva Junior, RG; Vasconcelos, PAS; Rodrigues, LRS. Acupuncture: an effective tool on procedures of in vitro fertilization? JBRA Assist Reprod. 2013; 17(1):53-55.

Costa, ALE. Monozygotic Twins and transfer at the blastocyst stage after ICSI. Human Reproduction, v. 16, p. 333-336, 2001.

Hu, Wei, Fang-xia Guan, Yuan Li, You-jia Tang, Feng Yang, and Bo Yang. "New methods for inducing the differentiation of amnioticderived mesenchymal stem cells into motor neuron precursor cells." Tissue and Cell (2013).

Kamiya K, Wang M, Uchida S, Amano S, Oshika T, Sakuragawa $\mathrm{N}$, Hori J. Topical application of culture supernatant from human amniotic epithelial cells suppresses inflammatory reactions in cornea. Exp Eye Res. 2005; 80:671-679.

Klimanskaya I, Chung Y, Becker S, Lu SJ, Lanza R. "Human embryonic stem cell lines derived from single blastomeres." Nature 444.7118 (2006): 481-485.

Kurisaki A, Ito $Y$, Onuma $Y$, Intoh A, Asashima $M$. In vitro organogenesis using multipotent cells. Hum Cell. 2010; 23:1-14.

Miki T, Lehmann T, Cai H, Stolz DB, Strom SC. Stem cell characteristics of amniotic epithelial cells. Stem Cells 2005; 23:1549-1559.

Nakanishi M, Kurisaki A, Asashima M: Basic knowledge of ES cells and iPS cells. Pharmacia. 2008; 44:1047-1051.

Vasconcelos PAS, Sene IS, Sousa GNS, Carvalho BF, Costa ALE. Correlation of transferency day and embryos quality with pregnancy rate. JBRA Assist Reprod. 2009; 13(1):21-24.

Zhao RC, Liao LM, Han Q. Mechanisms of and perspectives on the mesenchymal stem cell in immunotherapy. J Lab Clin Med 2004; 143(5): 284-291. 